\title{
Genetic and histologic evidence for autophagy in asthma pathogenesis
}

\section{Citation}

Poon, Audrey H., Fazila Chouiali, Sze Man Tse, Augusto A. Litonjua, Sabah N.A. Hussain, Carolyn J. Baglole, David H. Eidelman, et al. 2012. Genetic and histologic evidence for autophagy in asthma pathogenesis. Journal of Allergy and Clinical Immunology 129, no. 2: 569-571. doi:10.1016/j.jaci.2011.09.035.

\section{Published Version}

doi:10.1016/j.jaci.2011.09.035

\section{Permanent link}

http://nrs.harvard.edu/urn-3:HUL.InstRepos:27003504

\section{Terms of Use}

This article was downloaded from Harvard University's DASH repository, and is made available under the terms and conditions applicable to Other Posted Material, as set forth at http:// nrs.harvard.edu/urn-3:HUL.InstRepos:dash.current.terms-of-use\#LAA

\section{Share Your Story}

The Harvard community has made this article openly available.

Please share how this access benefits you. Submit a story.

\section{Accessibility}




\title{
Genetic and histological evidence for autophagy in asthma pathogenesis
}

\author{
Audrey.H. Poon, Ph.Da,b, Fazila Chouiali, M.Sca ${ }^{a}$, Sze Man Tse, MDCMc, Augusto.A. \\ Litonjua, MD,MPH, ${ }^{\mathrm{c}}$, Sabah NA. Hussain, MD, Ph.D ${ }^{\mathrm{a}, \mathrm{e}}$, Carolyn J. Baglole, Ph.D ${ }^{\mathrm{a}}$, David H. \\ Eidelman, MDa , Ronald Olivenstein, MD ${ }^{f}$, James.G Martin, MD, D.Sc ${ }^{a}$, Scott.T. Weiss, MD, \\ MS $^{\mathrm{c}, \mathrm{g}, \mathrm{h}}$, Qutayba Hamid, MD, Ph.D ${ }^{\mathrm{a}}$, and Catherine Laprise, Ph.D ${ }^{\mathrm{a}, \mathrm{b}}$ \\ aMeakins-Christie Laboratories, McGill University Health Centre, Montreal, PQ, Canada \\ bDepartment of Sciences fondamentales, Université du Québec à Chicoutimi, Chicoutimi, PQ, \\ Canada \\ 'Channing Laboratory, Brigham and Women's Hospital and Harvard Medical School, Boston, MA, \\ USA \\ ${ }^{\mathrm{d} D i v i s i o n}$ of Pulmonary and Critical Care Medicine, Department of Medicine, Brigham and \\ Women's Hospital and Harvard Medical School, Boston, MA, USA \\ ${ }^{e}$ Critical Care and Respiratory Divisions, Royal Victoria Hospital, Montreal, PQ, Canada \\ ${ }^{f}$ Montreal Chest Institute, McGill University Health Centre, Montreal, PQ, Canada \\ gPartners Center for Personalized Genetic Medicine, Partners Health Care; Massachusetts, USA \\ hDepartment of Medicine, Harvard Medical School, Boston, MA, USA
}

\section{Keywords}

asthma pathogenesis; autophagy; lung function; polymorphism; SNP; ATG5; autophagosome

To the Editor:

Asthma affects all age groups and presents itself as a spectrum of severity and symptoms. Reactive oxidative species (ROS) play a pivotal role in asthma pathogenesis. Exhaled levels of mediators associated with ROS positively correlate with asthma severity.(1) Autophagy, the process of cellular waste disposal through lysosomal -dependent pathways, is induced by ROS to remove oxidized proteins or organelles to minimize tissue damage.(2) Although autophagy is augmented in the lungs of COPD patients compared to healthy control subjects (3), evidence for autophagy in asthma, particularly moderate-to-severe asthma, has not been reported. We hypothesize that autophagy is associated with asthma pathogenesis, and sought to detect its presence using both genetic and histological approaches.

\footnotetext{
(C) 2011 American Academy of Allergy, Asthma and Immunology. Published by Mosby, Inc. All rights reserved. qutayba.hamid@mcgill.ca .

Publisher's Disclaimer: This is a PDF file of an unedited manuscript that has been accepted for publication. As a service to our customers we are providing this early version of the manuscript. The manuscript will undergo copyediting, typesetting, and review of the resulting proof before it is published in its final citable form. Please note that during the production process errors may be discovered which could affect the content, and all legal disclaimers that apply to the journal pertain.

Disclosure of potential conflict of interest: No conflict of interest and relationship with commercial interests related to this manuscript to disclose.
} 
We conducted a genetic association study to investigate whether single nucleotide polymorphisms (SNPs) in genes of the autophagy pathway are associated with asthma. We selected 5 genes of the autophagy pathway (unc-51-like kinase 1(ULKI), sequestosome 1 (SQSTM1), microtubule-associated protein 1 light chain 3 beta (MAPILC3B), beclin 1 (BECN1) and autophagy related 5 homolog (ATG5)). (2) We tested for genetic associations in an asthma family-based study from northeastern Quebec, Canada (The Saguenay-LacSaint-Jean (SLSJ) asthma Study) using the family based association test (FBAT) statistic and UNPHASED software for an odds ratio estimate. $(4,5)$ Patient recruitment has previously been described.(6) These SNPs have been genotyped previously in a genomewide association study.(6) To reduce the likelihood of false positive findings, we reset the statistical significance threshold from $\mathrm{p}=0.05$ to $\mathrm{p}=0.001$ according to the Bonferroni method. To confirm our positive findings, we tested the association in a second family based population; the non-Hispanic Caucasian participants of the Childhood Asthma Management Program (CAMP), and patient recruitment has previously been described. (7) The SLSJ local ethics committee and the Institutional Review Board for CAMP approved the study, and all subjects gave informed consents.

In the SLSJ asthma study a total of 1338 individuals (483 nuclear families) with known asthma status were included in the analysis, and 336 individuals were either probands or affected siblings. Of this group, the male:female ratio was 0.83 . The mean age was 16.45 (standard deviation (SD) +/- 9.43) years. $77.1 \%$ were atopic. The mean (SD) forced expiratory volume in 1 second $\left(\mathrm{FEV}_{1}\right) \%$ predicted was $94.1(20.1) \%$. A total of 39 SNPs were tested, and after Bonferroni correction, SNP rs $12212740 \mathrm{G}>\mathrm{A}$ of ATG5 remained statistically significant (Table 1 ). Allele $\mathrm{G}$ with allele frequency of 0.88 is over - transmitted to asthmatic offspring ( $\mathrm{p}=0.0002),($ Odds ratio $=1.35$, (95\% confidence interval $=1.01$ and 1.89). SNP rs 12212740 was not associated with asthma in CAMP, however, it was associated with pre - bronchodilator $\mathrm{FEV}_{1}$ (pre-FEV ( $_{1}$ (adjusted for age, sex and height) $(\mathrm{p}=0.04)$. In the SLSJ cohort, $r \mathrm{~s} 12212740$ was associated with pre-FEV ${ }_{1}(\mathrm{p}=0.007)$. In both populations, allele $\mathrm{G}$ was negatively associated with adjusted pre-FEV ${ }_{1}$. SNP rs 12212740 is located in intron 3 of ATG5, 7kb downstream and 8kb upstream of exon 3 and 4, respectively. At present, the functional consequence of SNP rs12212740 is unknown, and it is probable that the association is due to the linkage disequilibrium between SNP rs12212740 and the true causative variant. Nevertheless, the association between a genetic variant of ATG5 and pre-FEV ${ }_{1}$ in both study populations suggest that autophagy is associated with reduced lung function in asthmatic subjects.

To determine if autophagy is present in the airways of asthmatic individuals, bronchial biopsy stored at the Tissue Bank of the Respiratory Health Network of the Fonds de la Recherché en Santé du Québec (McGill University Health Centre site) were obtained. Patient recruitment and bronchoscopy have previously been described.(8) Bronchial biopsy tissue from a moderately severe asthma patient and a healthy control were viewed by electron microscopy (EM) for double membrane autophagosomes.

Here, we demonstrated by EM in a tissue sample from a moderately severe asthma subject evidence of autophagy in asthma pathogenesis. Using EM, double membrane autophagosomes were detected in fibroblasts and epithelial cells. A representative fibroblast from a bronchial biopsy tissue of a moderate asthma subject is depicted in Figures 1A-C, and epithelial cells in figures $2 \mathrm{~A}-\mathrm{C}$. Corresponding fibroblast and epithelial cells from a healthy control are depicted in figures 1D-F and figures 2D-F, respectively, where fewer or no autophagosome was detected.

This is the first report to present genetic and histological evidence of autophagy in asthma pathogenesis. ATG5 is involved in the elongation step of the autophagosome formation. 
ATG5 forms a complex with ATG12 and ATG16L1 and the complexes are found on the outer membrane of the forming autophagosome.(2) We speculate that the positive association of allele $\mathrm{G}$ with asthma and the negative association with pre-FEV $\mathrm{F}_{1}$ in asthmatics may be due to the inverse relationship between pre-FEV 1 and asthma severity(9). If allele $\mathrm{G}$ is a risk factor for low pre- $\mathrm{FEV}_{1}$, given that pre- $\mathrm{FEV}_{1}$ tends to be lower in those with more severe forms of asthma, the allele would also increase the risk of developing moderate-tosevere asthma. The genetic association of $A T G$ with pre-FEV ${ }_{1}$ in asthmatics and the detection of autophagosomes in fibroblasts and epithelial cells in tissues from a moderately severe asthma patient suggest an association between autophagy and reduced lung function in asthmatic subjects. At present the mechanistic pathway of autophagy in asthma is unclear, but it opens up a new avenue to explore the mechanism of the chronic nature of asthma pathogenesis.

\section{Acknowledgments}

We thank Glenda Wright, Louise Pelletier and Anja Geitmann for their assistance in EM.

This study is supported by Richard and Edith Strauss Foundation, Canada Research Chair on Genetic Determinants of Asthma and American Thoracic Society Research Grant. The CAMP Genetics Ancillary Study is supported by U01 HL075419, U01 HL65899, P01 HL083069, R01 HL086601 and T32 HL07427 from the NHLBI, National Institutes of Health (NIH).

\section{Reference List}

(1). Horvath I, Donnelly LE, Kiss A, Kharitonov SA, Lim S, Chung KF, et al. Combined use of exhaled hydrogen peroxide and nitric oxide in monitoring asthma. Am J Respir Crit Care Med. 1998; 158(4):1042-1046. [PubMed: 9769258]

(2). Szumiel I. Autophagy, reactive oxygen species and the fate of mammalian cells. Free Radic Res. 2011; 45(3):253-265. [PubMed: 20964552]

(3). Chen ZH, Kim HP, Sciurba FC, Lee SJ, Feghali-Bostwick C, Stolz DB, et al. Egr-1 regulates autophagy in cigarette smoke-induced chronic obstructive pulmonary disease. PLoS One. 2008; 3(10):e3316. [PubMed: 18830406]

(4). Dudbridge F. Likelihood-based association analysis for nuclear families and unrelated subjects with missing genotype data. Hum Hered. 2008; 66(2):87-98. [PubMed: 18382088]

(5). Lake SL, Blacker D, Laird NM. Family-based tests of association in the presence of linkage. Am J Hum Genet. 2000; 67(6):1515-1525. [PubMed: 11058432]

(6). Moffatt MF, Gut IG, Demenais F, Strachan DP, Bouzigon E, Heath S, et al. A large-scale, consortium-based genomewide association study of asthma. N Engl J Med. 2010; 363(13):12111221. [PubMed: 20860503]

(7). The Childhood Asthma Management Program (CAMP): design, rationale, and methods. Childhood Asthma Management Program Research Group. Control Clin Trials. 1999; 20(1):91120. [PubMed: 10027502]

(8). Shannon J, Ernst P, Yamauchi Y, Olivenstein R, Lemiere C, Foley S, et al. Differences in airway cytokine profile in severe asthma compared to moderate asthma. Chest. 2008; 133(2):420-426. [PubMed: 18071017]

(9). Lange P, Parner J, Vestbo J, Schnohr P, Jensen G. A 15-year follow-up study of ventilatory function in adults with asthma. N Engl J Med. 1998; 339(17):1194-1200. [PubMed: 9780339] 


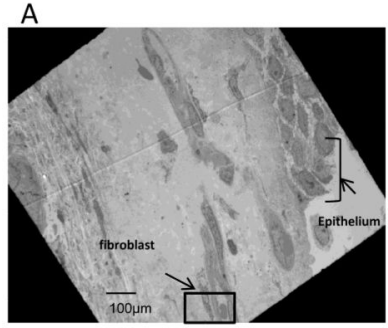

B

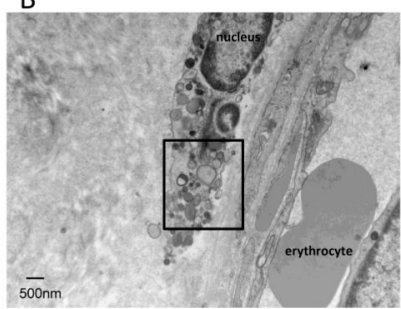

D

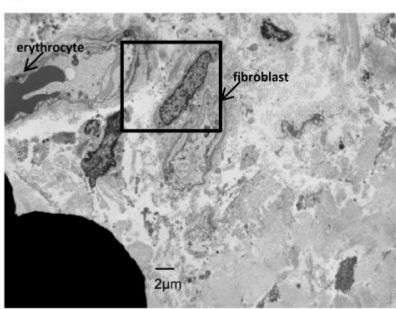

E

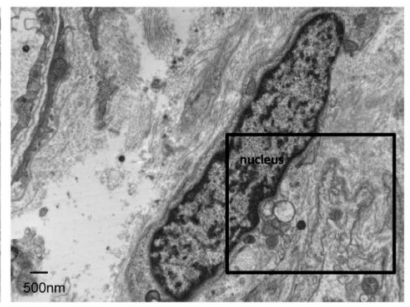

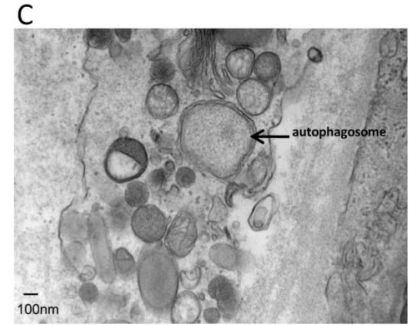

F

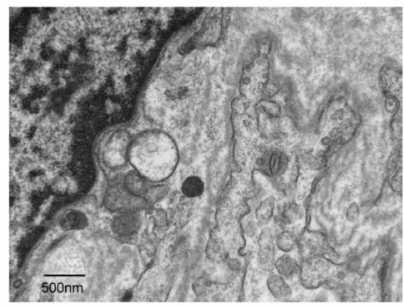

Fig 1.

A double membrane autophagosome was detected in a fibroblast from a bronchial biopsy tissue sample of a moderate asthma subject. Tissue was viewed at magnifications of (A) 1480x, (B) 16100x and (C) 62200x. Boxed areas were viewed under higher magnification in subsequent figures. An arrow indicated an autophagosome. Corresponding fibroblast from a healthy subject was viewed at magnifications of (D) 4030x, (E) 16100x and (F) 37000x, respectively. 
A
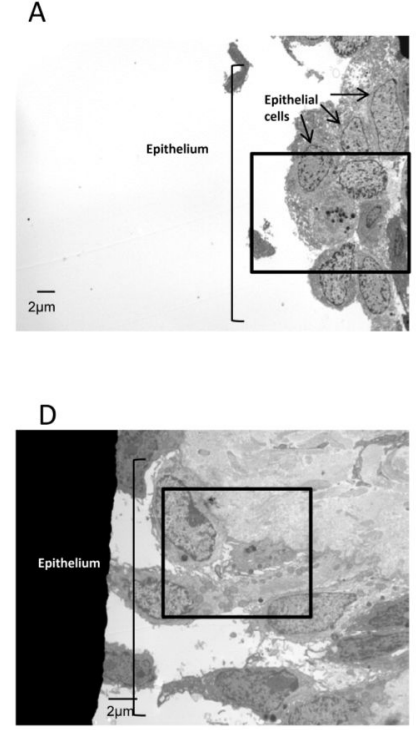
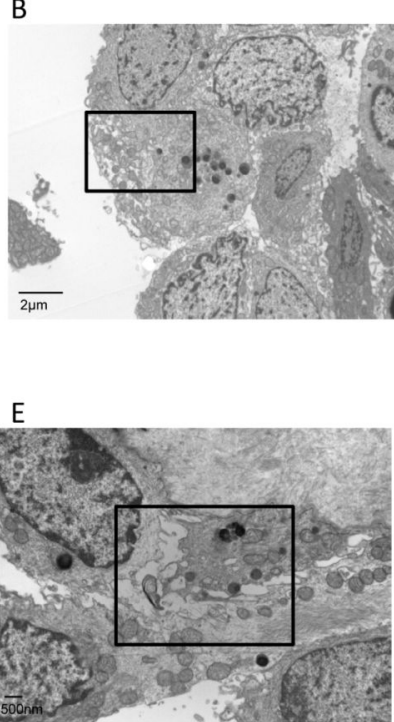

C
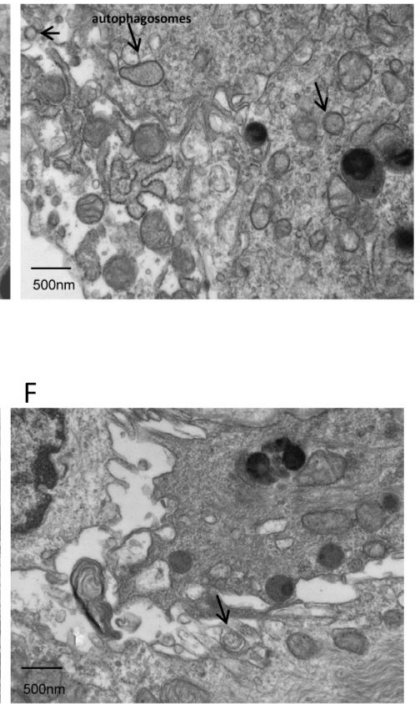

Fig 2.

Autophagosomes were detected in bronchial epithelial cells from a moderate asthma subject. Tissue was viewed at magnifications of (A) 4030x, (B) 9760x and (C) 37000x, respectively. Corresponding epithelial cells of a healthy subject was viewed at magnifications of (D) 6390x, (E) 16100x and (F) 37000x, respectively. Arrows pointed at double membrane autophagosomes. 


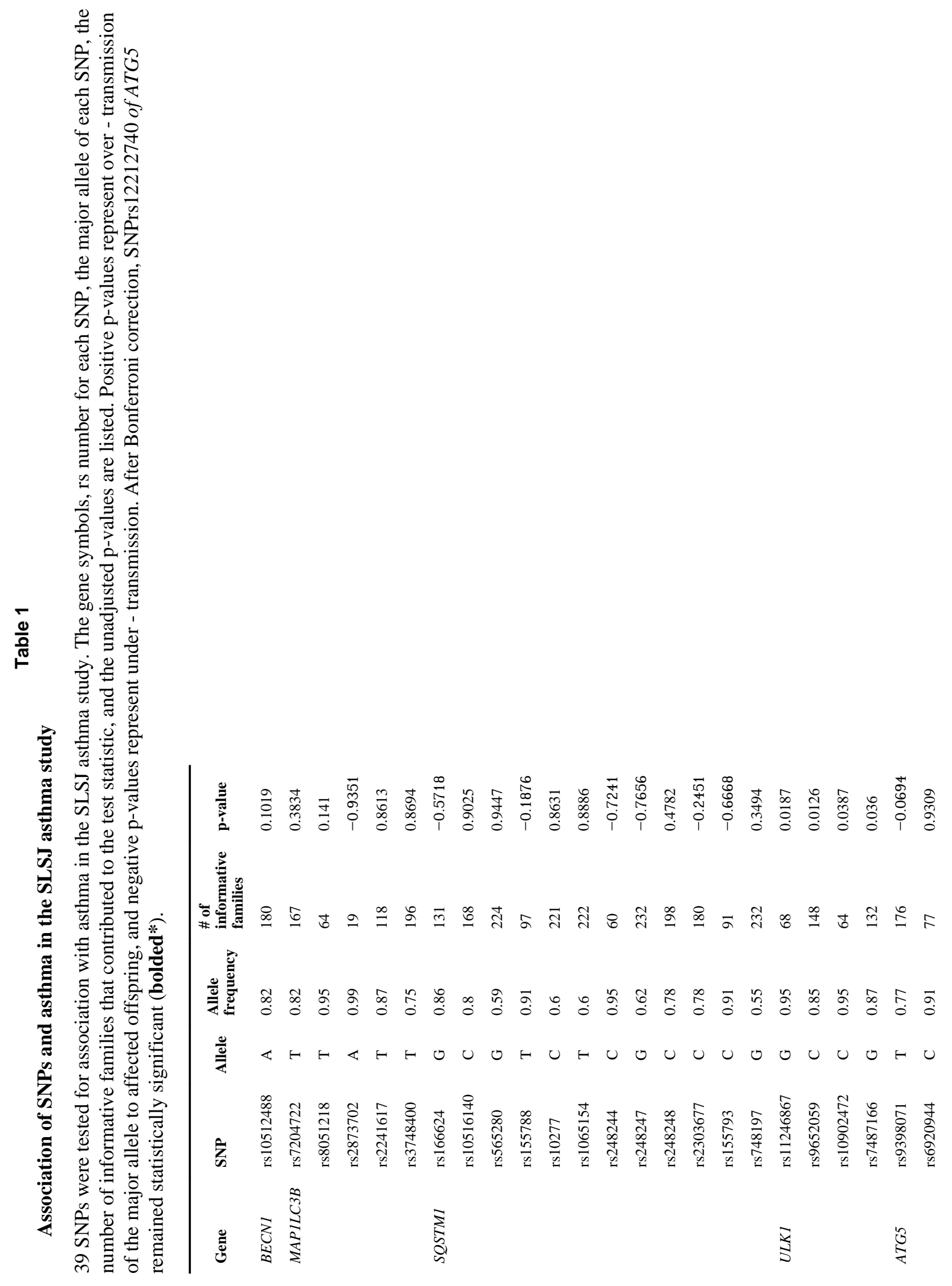




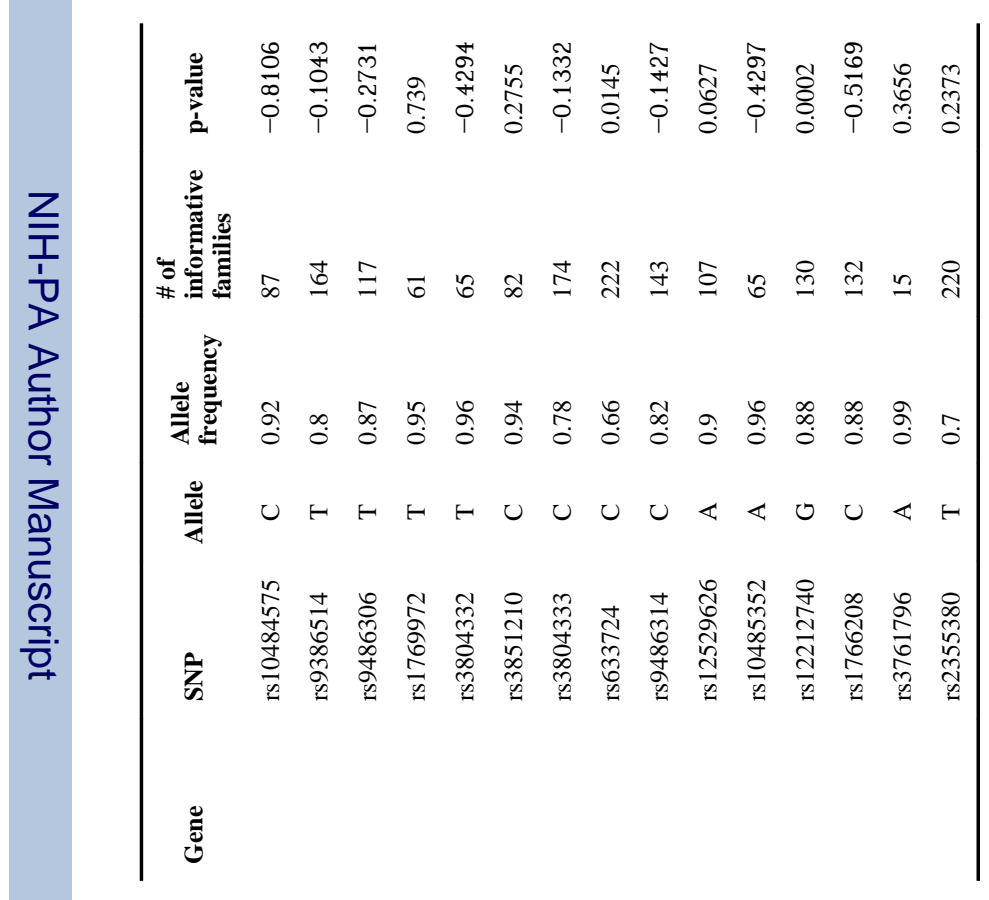

